\title{
Undifferentiated carcinoma of the corpus uteri
}

INSERM

\section{Source}

INSERM. (1999). Orphanet: an online rare disease and orphan drug data base.

Undifferentiated carcinoma of the corpus uteri. ORPHA:213721

Undifferentiated carcinoma of the corpus uteri is a rare cancer of corpus uteri presenting as a large, polypoid, intraluminal mass with necrosis, composed of small to intermediatesize, relatively uniform, dyshesive cells displaying no differentiation. It usually presents with dysfunctional bleeding or vag inal discharge and, less often, abdominal pain. Association with Lynch syndrome was reported. 